\title{
Teacher Education and Total Quality Management (TQM)
}

\author{
Ankit Chauhan 1 , Poonam Sharma 2
}

The American Commission on Teacher Education rightly observes,

"The quality of a nation depends upon the quality of its citizens. The quality of its citizens depends not exclusively, but in critical measure upon the quality of their education, the quality of their education depends more than upon any single factor, upon the quality of their teachers."

With changing patterns of education delivery from face to face to online, course content, nature of learner, and organizational structures, the concept of quality has become an inherent component of the educational process for its success. Globally various bodies have been established to develop guidelines for quality products and services, and their maintenance. The globalization of education, migration of students from one community to other, one country to another, provides adequate causes for concerns to the educationists and administrations. Total Quality Management (TQM) in education is a timely tool, which must be clearly understood, adopted and implemented as soon as possible.

Concept of Teacher Education- It is well known that the quality and extent of learner achievement are determined primarily by teacher competence, sensitivity and teacher motivation.

According to NCTE, A programme of education, research and training of persons to teach from pre-primary to higher education level is known as teacher education. It is a programme that is related to the development of teacher proficiency and competence that would enable and empower the teacher to meet the requirements of the profession and face the challenges therein.

According to Goods Dictionary of Education Teacher Education means, "all the formal and non-formal activities and experiences that help to qualify a person to assume responsibilities of a member of the educational profession or to discharge his responsibilities more effectively."

\footnotetext{
${ }^{1}$ Assistant Professor, RIE Ajmer

${ }^{2}$ Assistant Professor, RIE Ajmer
}

(C) 2015, A Chauhan, P Sharma; licensee IJIP. This is an Open Access Research distributed under the terms of the Creative Commons Attribution License (http://creativecommons.org/licenses/by/2.0), which permits unrestricted use, distribution, and reproduction in any Medium, provided the original work is properly cited. 
In 1906-1956, the programme of teacher preparation was called teacher training. It prepared teachers as mechanics or technicians. It had narrower goals with its focus being only on skill training. The perspective of teacher education was therefore very narrow and its scope was limited.

As W.H. Kilpatrick put it, "Training is given to animals while education is to human beings."

Teacher Education encompasses teaching skills, sound pedagogical theory and professional skills.

\section{Teacher Education= Teaching skills + Pedagogical theory + professional skills.}

Teaching skills- would include providing training and practice in the different techniques, approaches and strategies that would help the teachers to plan and impart instruction, provide appropriate reinforcement and conduct effective assessment. It includes effective classroom management skills, preparation and use of instructional materials and communication skills.

Pedagogical Theory- includes the philosophical, sociological and psychological considerations that would enable the teachers to have a sound basis for practicing the teaching skills in the classroom. The theory is stage specific and is based on the needs and requirements that are characteristics of that stage.

Professional Skills- include the techniques, strategies and approaches that would help the teachers to grow in the profession and also works towards the growth of the profession. It includes soft skills, counseling skills, interpersonal skills, computer skills, information retrieving and management skills and above all lifelong learning skills.

Concept of Quality- Quality became very common word nowadays. What actually quality means. It is very familiar term but its meanings and uses vary widely. In general term quality is the position of a 'product' or a 'process' attribute on good, bad scale. It is often associated or linked with defects and deficiencies in products or process. According to Johnson (1987)Quality is the capability of products or services to knowingly satisfy those preconceived composite wants of the user(s) that are intelligently related to the characteristics of performance, and do not cause major overt or covert reactions or actions by other people.

"Fitness of use" by Juran(1974)

"Conformance to requirements." by Crosby (1984)

Deming (1986) defines quality as "a predictable degree of uniformity and dependability at low cost and suited to the market."

From the above concepts of quality when two aspects combined together may help in understanding the concept in an optimum way. 
1. Relates to the features and attributes of the product or services.

2. Absence of deficiencies in the products.

Thus quality can be defined as the totality of features and characteristics of a product or service that bear on its ability to satisfy stated or implied needs. Alexander Astin (1993) pointed out in the discussion on quality in education system,

You-cannot-define-it-but-you-know-it-when-you-see-it.

According to him there are four views on excellence in quality higher education-

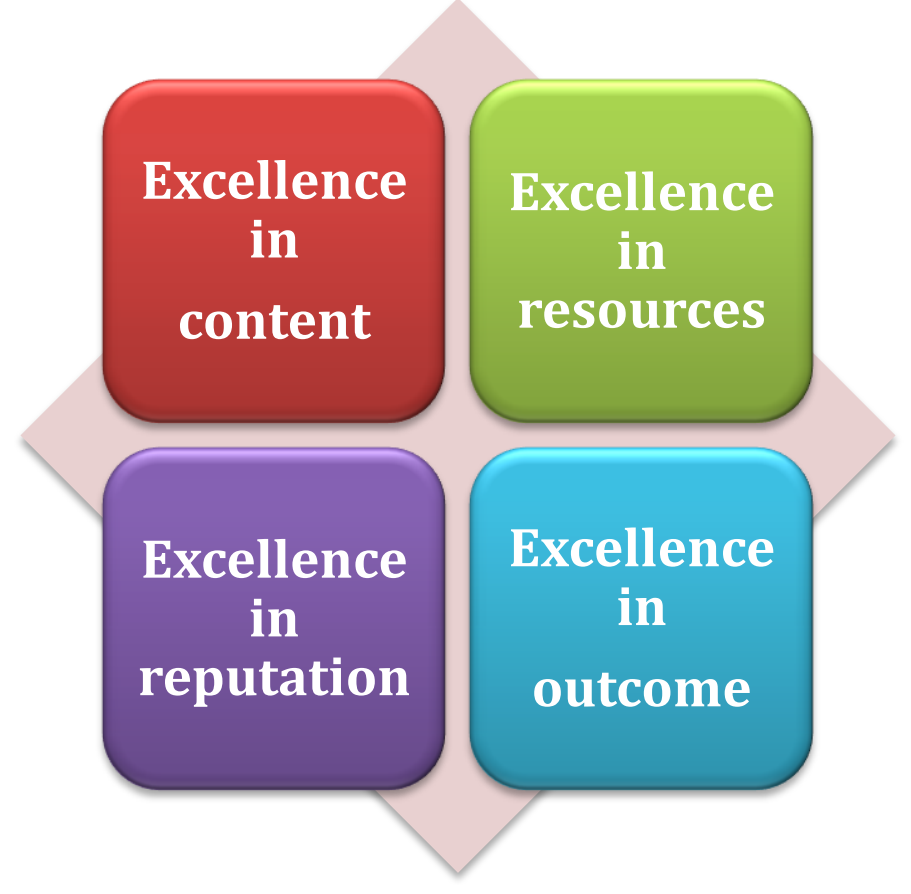

1. Excellence in reputation

2. Excellence in resources

3. Excellence in content

4. Excellence in outcome

Inculcating Total Quality Management (TQM) in Teacher Education- Teacher education institutes have a important role in improving the standards of educational system by preparing effective teachers. Quality of nation is equal to quality of its citizens. It is not easy to introduce the concept of TQM into teacher education. TQM focuses strongly on the learner and the teacher. It recognizes that all teaching-learning requires 'process' that enable learner requirement to be met the ability to meet learner's requirements is vital. Quality involves everyone including teaching staff no-teaching staff and management. 
TQM is a system of continuous improvement employing participative management centered on the needs of customers.TQM is new practices in businesses as well as in government the military and education. So TQM aims at improving the quality of work of all people at all levels in all functional areas of the organization.

\section{Component of TQM-}

TQM has five components.

1. The Customer-The customer is anyone internal or external, who receive or is affective by the product, process or services.

2. Continuous Improvement-Continuous improvement is essential to reach the stage of ' 0 ' defects.

3. Training and Development- Faculty development should ensure diligent updating at per with state of the art.

4. Team work- Team work is the key to achieve team work.

5. Measurement- Monitoring progress with review of objectives is a necessary corollary.

\section{Objectives of TQM -}

TQM has following objectives,

1. Continuous quality improvement and total commitment to quality.

2. User oriented service.

3. Team work, total participation.

4. Give high priority to training.

5. Continuous cost reduction.

\section{Principals of TQM-}

According to Dr. W. Edwards Deming, TQM has following principles-

1. Embrace new philosophy

2. Drive out fear.

3. Institute leadership.

4. Break down barriers between departments.

5. Remove barriers to pride of workmanship.

6. Human based management.

\section{Six Basic Steps in TQM-}

These are-

1. Planning

2.Organizing

3.Executing

4.Evaluation

5.Feed back 
6. Bench marking

\section{Process of TQM-}

TQM has six stages of better processing.

\section{Planning-}

Planning for quality concern includes many points such as-

-Aim

-Methods

-Need

-Future role

\section{Experiment-}

Experiment is concerned with trail version of any planning-

-Policy role

-Future of particular policy

-Proper resources

\section{Monitoring-}

Monitoring includes-

-Work experiences

-Making corrections

-Detecting problems

\section{Assessment-}

It includes-

-Assessment of inputs

-Assessment of process

-Assessment of results

\section{Improvement-}

It is aimed at determining resources of particular concerned issue, concern with the result of above maintained stages.

\section{CONCLUSION-}

In all fields, especially education quality has an important matter. Total Quality Management as a necessary element always has a direct influence on the human improvement. It can be also led to high commitment and sprit in work environment. However with the expansion of teacher education institutes the assurance of quality has been challenged which is the basic requirement in knowledge society. Due emergence of knowledge society the need of quality assurance has further multiplied its intensity. The application of quality assurance in industrial sector helps us designing quality assurance strategies for teacher education. i) Maintain ii) Enhancing iii) Ownership iv) Checking quality As a whole quality assurance in teacher education may be ensured by studying its customer than assuring quality at every stage because all these parts are interrelated. 


\section{REFERENCES}

1. Sciences - Volume 16, Number 4 (2010). | 8. MukhopadhyayMarmar, 2001. Total Quality Management in Education. Reviewed by Dr. Ramesh C. Sharma, Indira

2. Gandhi National ,India | 9. Pour Hadi Mohammad, and K. Yeshodhara Total Quality Management (TQM) in Education -Perception of Secondary School Teachers.

3. 2, Issue. 6, July 2012. | 12. WillaingGlasser, M. D. (1992). The Quality School teacher.

4. Sallis Edward,Total Quality Management in Education,Kogan Page(2000),Pg.No138143.

5. Karabulut, 2004 Karabulut, A., (2004). Total quality management in education. Journal of Standard, 513, 48-52.

6. Vocational, 2012 Vocational and technical education Education Reform Initiative of the updated situation analysis of Koç Holding. 2012.

7. The ministry of National Education, 2012 The ministry of National Education (MEB) Vocational and Technical Education Workshop, Antalya, 2012.

8. Yenersoy, 1997Yenersoy, G. (1997). Total quality management “The First Step In Search Of Perfection Journey". Istanbul. Rota publishing. 